\title{
The changing social environment for adolescents in Kassena- Nankana District of northern Ghana: Implications for reproductive behavior
}

Barbara Mensch

Population Council

Daniel Bagah

Wesley H. Clark

Population Council

Fred N. Binka

Follow this and additional works at: https://knowledgecommons.popcouncil.org/departments_sbsr-pgy

Part of the Demography, Population, and Ecology Commons, Family, Life Course, and Society Commons, and the International Public Health Commons How does access to this work benefit you? Let us know!

\section{Recommended Citation}

Mensch, Barbara, Daniel Bagah, Wesley H. Clark, and Fred N. Binka. 1998. "The changing social environment for adolescents in Kassena-Nankana District of northern Ghana: Implications for reproductive behavior," Policy Research Division Working Paper no. 110. New York: Population Council. 
The Changing Social Environment for Adolescents in the Kassena Nankana D istrict of Northem Ghana: Implications for Reproductive Behavior

Barbara S. M ensch

D aniel Bagah

Wesley H . C lark

Fred Binka 


\title{
The Changing Social Environment for Adolescents in the Kassena-Nankana District of Northern Ghana: Implications for Reproductive Behavior
}

\author{
Barbara S. Mensch \\ Daniel Bagah \\ Wesley H. Clark \\ Fred Binka
}

Barbara S. Mensch is Associate, Policy Research Division, Population Council. At the time this research was conducted, Daniel Bagah was Mellon Ghana Postdoctoral Fellow, Navrongo Health Research Centre, Navrongo, Ghana. Wesley H. Clark is Data Management Analyst, Policy Research Division, Population Council. Fred Binka is Director, Navrongo Health Research Centre, Navrongo, Ghana.

The authors gratefully acknowledge the support of the United Nations Population Fund and thank Nathan Mensah for assistance with analysis of the survey data. They also thank Nadra Franklin for sharing her materials on marriage in the District and Cynthia Lloyd and James Phillips for comments on an earlier draft. The paper was presented at the 1998 Annual Meeting of the Population Association of America, Chicago, 2-4 April. 


\begin{abstract}
This study reports on a primarily qualitative investigation of adolescent reproductive behavior in the Kassena-Nankana District, a rural isolated area in northern Ghana, where traditional patterns of marriage, family formation, and social organization persist. The study is based on in-depth interviews and focus groups with adolescents, parents, chiefs and traditional leaders, teachers, youth leaders, and health workers, supplemented by quantitative data from the 1996 wave of a panel survey of reproductiveaged women conducted by the Navrongo Health Research Centre. The social environment faced by adolescent boys and girls in the Kassena-Nankana District and its links to reproductive behavior are described. The principal question is whether in this remote, rural area, the environment has been altered in ways that have undermined traditional sexual and reproductive patterns. The survey data indicate a considerable increase in educational attainment among younger women. In addition, it appears that the incidence of early marriage has begun to decline. The qualitative data suggest that social institutions, systems, and practices such as female circumcision, which previously structured the lives of adolescent boys and girls, have eroded, leading to an apparent increase in premarital sexual activity. The implications of these developments for adolescent health and wellbeing in the District are discussed.
\end{abstract}

This material may not be reproduced in any form without written permission from the authors. 
While early childbearing has always been a notable feature of demographic behavior in sub-Saharan Africa, a National Academy of Sciences volume on the region argues that a transformation is taking place in the nature of adolescence and the social context in which adolescent fertility is situated, particularly in urban areas (Bledsoe and Cohen 1993). The limited data available point to a decline in age of menarche, a rise in schoolingparticularly for girls - an alteration in employment patterns, and an increase in the mobility of young people. Adolescence, the period between the onset of secondary sex characteristics and marriage, appears to be a more significant phase in the life cycle of girls now than in the past. Indeed, as a distinct stage in the life cycle, adolescence, at least for girls, is said to be a new "phenomenon" in the region. In the past, the transition from childhood to adulthood was made "during the relatively short period of initiation," with distinct customs, associated with each ethnic group, regulating social behavior (see, for example, Balmer 1994:2). ${ }^{1}$

With the greater prominence of adolescence for girls in sub-Saharan Africa, there is believed to be an intensification in the sexual pressures boys and men put on young women, reduced control over young people by the older generation, and a concomitant rise in teenage childbearing occurring outside of a sanctioned relationship (Bledsoe and Cohen 1993). Opportunities for secondary schooling that now exist provide young men with considerable autonomy, removing them from the family compound or home and the watchful eyes of elders. While data are not available to document a decline in age of first intercourse for males in sub-Saharan Africa, there is a perception that in contrast to the present, "in the past a young man might have had little opportunity for full sexual expression until his late twenties" (Bledsoe and Cohen 1993:85). Moreover, young men who are not in a formalized union are believed increasingly unwilling to acknowledge paternity, whether because of economic reasons (i.e., the rising cost of childrearing), 
the greater exposure to Western life styles, or simply because they are less mature, having engaged in sexual activity and become fathers at an earlier age.

This paper reports on a qualitative research investigation of adolescence in the Kassena-Nankana District of Ghana, a rural, isolated area in the country's Upper East region, where traditional patterns of marriage, family formation, and social organization persist (Binka, Nazzar, and Phillips 1995). We first discuss the literature describing the transition to adulthood in traditional Kassena-Nankana society, followed by a summary of the research on recent changes in adolescence in sub-Saharan Africa. Using 51 in-depth interviews and 15 focus groups with adolescents, parents, chiefs, other traditional leaders, teachers, youth leaders, and health workers, we then describe the social environment currently faced by adolescent boys and girls in the Kassena-Nankana District and explore the implications for reproductive behavior. The principal question addressed is whether, in this remote rural setting, the social and economic landscape has shifted in ways that undermine traditional sexual and reproductive behavior. We draw on relevant data from large-scale demographic surveillance and survey initiatives in the District to provide a quantitative context in which to set the qualitative findings.

\section{THE SETTING}

The Kassena-Nankana District of Ghana is in the northeastern part of the country, bordering Burkina Faso. The District, which has a population of around 175,000 , is classified ecologically as belonging to the Guinea savanna. The area consists of semi-arid scrubland; natural vegetation is limited to widely spaced trees, shrubs, and grasses and resembles the Sahelian countries to the north more than the export-growing cocoa regions of Brong- 
Ahafo and Ashanti to the south (Fayorsey, Adongo, and Kajihara 1994; Binka et al. 1997). The soil is of poor quality, and rainfall, which is limited to the months between June and October, is low and considered unreliable for agricultural purposes (Tonah 1993). Subsistence agriculture predominates and the District is considered among the poorest in the country. Seasonal malnutrition is quite common.

The District consists of some 90 villages organized into ten paramountcy chiefdoms $^{2}$ and is over 80 percent rural. Navrongo, the District capital, has an estimated population exceeding 10,000. While both the Kassena and Nankana speak languages belonging to the Gur group, Kassem, spoken by slightly more than half of the District's population, is a Grusi language, and Nankam is a Mole-Dagbane language (Naden 1974; Tonah 1993). Although linguistically distinct, the groups are culturally homogeneous, having social structures and religious practices similar to those of other Voltaic speakers in the North (Fayorsey, Adongo, and Kajihara 1994). Indeed, because of "increasing intermarriages and urbanization it has become very difficult to make a distinction between the two ethnic groups" (Tonah 1993:60). ${ }^{3}$

Compounds, which consist of multiple mud huts, generally include a head - the patriarch—his wives, his married sons and their wives, and his grandchildren (although married sons, with the exception of the eldest, may build their own compounds next to their father's). A compound can contain several family groups and may include up to 50 people (Abasi 1995). The lineage is composed of many extended family compounds. Descent among the Kassena-Nankana is patrilineal. Clans are exogamous, with marriage forbidden between members of the same clan or those from the same natal village and even adjoining villages. Residence is patrilocal, with the wife 
taking up residence in the husband's compound after marriage (Fayorsey, Adongo, and Kajihara 1994). Authority rests with the oldest male member of the lineage, who as the ritual head of the family consults with the soothsayer. The soothsayer has the critical task of communicating with the ancestral spirits, who are consulted on all important decisions involving the family, including marriage (Adongo, Phillips, and Binka 1998). The KassenaNankana are animists, and even those who identify themselves as Christians or Muslims often adhere to some traditional practices, especially when it comes to funerals, for the ancestral world is believed to be entered at death (Abasi 1995).

In describing the cultural setting of the Kassena-Nankana District, Binka, Nazzar, and Phillips (1995) observe that a "climate of traditionalism" exists. As a background to a large-scale health and family planning project in the area, researchers have investigated the social, religious, and cultural constraints to fertility regulation (see, for example, Agulah, Akweongo, and Phillips 1998; Adongo, Phillips, and Binka 1998). However, the focus of the work has been on older married women. The position of women is described as being particularly bleak. Few are believed to have any formal schooling and the prevailing form of social organization, which gives compound heads a "gate-keeping" role, allows women little autonomy. According to Nazzar et al. (1995), the limited mobility of women and their low level of literacy, combined with a dispersed pattern of settlement, effectively isolate women from new ideas and institutions. As for adolescents, they note:

The problems of young women are particularly acute. Arranged marriage among teenagers is virtually universal. Although premarital fertility is believed to be low, fertility soon after mar- 
riage is highly desired. Thus, high adolescent marital fertility rates occur in a population where maternal mortality is known to be extremely high for first-born children. (Nazzar et al. 1995:310).

While adolescent behavior has not been a particular concern of the social scientists investigating the District, from the research conducted we speculate that the social environment and institutions that structure the lives of young people in this rural, relatively remote area have changed little in recent years. Before analyzing our qualitative data, collected to provide insight into the lives of young people currently living in the Kassena-Nankana District, we first describe the "adolescent experience" (inasmuch as there was one, at least for girls) in "traditional" West Africa and in the north of Ghana in order to make comparisons with the present.

\section{ADOLESCENT SOCialization, SEXUAlity, AND MARRiage: Traditional PATTERnS OF BEHAVIOR}

To the extent that earlier observers of African society concerned themselves with the transition to adulthood, their attention was limited to marriage customs and initiation rites. While the notion of "traditional" culture is anathema to anthropologists, who rail against static descriptions of pre-modern societies, it is nonetheless convenient to try to characterize the lives of young people in colonial West Africa. We need to do so if only to determine whether the adolescent experience observed in contemporary Kassena-Nankana District has evolved in recent years. While it is possible to gain some insight into the lives of young people from the sparse literature that exists, where necessary we rely on recent accounts of apparently long-standing traditions, which, even if breaking down, still exist in some areas of the District. 
According to Cardinall, a local administrator in the British colonial regime during the early part of the century whose commentaries are well regarded by contemporary anthropologists (Wilson 1998), marriage occurred directly after circumcision for girls ${ }^{4}$ (Cardinall 1926). However, in a discussion of marital rites, he notes that during courtship some parents "are quite content to permit intercourse, since they still retain the ownership of the girl, and, unless her temporary husband can satisfy their requirements in the shape of presents, will eventually own the children" (ibid.:76). Writing 30 years ago about the Sisala, an ethnic group who live immediately to the west of the Kassena-Nankana District, Grindal (1982) notes that while premarital sexual unions were disapproved of, premarital sexual activity apparently was not. "[S]uch behavior is nonetheless expected of young men and women, and virginity is not seen as a prerequisite of marriage" (ibid.:48). Nevertheless, premarital liaisons were expected to lead to courtship and marriage, particularly if there was a conception. Moreover, there was concern if sexual activity occurred at a very young age. Too early sexual activity was said to cause "a boy to become weak and impotent and a girl to become barren and lazy" (ibid.). ${ }^{5}$ According to Smock's (1977) analysis of pre-colonial Ghana, in which she commented about premarital sexual behavior (generalizing, in this case, about both the "northern groups" and the Akan and the Ewe, the two dominant ethnic groups in the South), these societies did not consider female chastity to be particularly important. More critical was that a girl did not become sexually active and pregnant before the celebration of puberty rites, which were usually held soon after menarche so as to reduce the possibility of an unsanctioned birth. Indeed, Cardinall emphasized that virginity was considered an "honour... at the time of excision" (1926:76). 
A British colonial administrator's commentary from the 1930s confirms that sexual activity prior to marriage was, if not entirely condoned, certainly accepted. Rattray, who had lived in the region nearly 25 years when he wrote The Tribes of the Ashanti Hinterland, ${ }^{6}$ described "the mating of lovers" in detail, using vignettes based on observation. ${ }^{7}$ He noted that whether acquiring a lover or a wife, the same method of courtship was followed. Yet, because of tribal law, lovers who came from the same town and thus were referred to as tapa (sisters) although not sharing the same parents, were prohibited from marrying. He stated that courtship "is done quite openly with the full consent of her [the girl's] parents" (Rattray 1932:153). The young man justifies his desire for a lover on the grounds that he needs experience prior to marriage. "I may not marry you any day at all, but a man learns how to make love to women from his 'sister.' If one does not seek one's sister, how will he understand the finding of wives and avoid being laughed at by them[?]" (ibid.).

Rattray confirms that intercourse for girls prior to circumcision, while known to have occurred, was not sanctioned:

When a girl, during the operation, is found not to be a virgin, she will be shamed amongst her neighbors. On account of this, it is very difficult to get a young girl to consent (to intercourse) before she has been cut. "... Do not be in haste, let me get "cut" first, for I don't wish to get "cut" and be disclosed to be suulino (not a virgin) and have people laughing at me...' As young girls and boys are often sleeping together on the same mat, it follows that sometimes a girl will weaken. In such a case, when the time 
for cutting comes, her zaba (lover) pays (bribes) the operator to save the disgrace following the exposure of her condition (ibid.:155 and 169).

If discovered, there were consequences for the boy as well as the girl: “...it is shameful for him among his companions; they will tell him that he has destroyed the girl" (ibid.:169). However, to what extent the boy was ostracized or was forced to pay some penalty is not specified, nor is it known whether the girl's chances of marriage were actually reduced.

From available accounts, circumcision appeared to be universal in the northern part of the country and entailed both the physical act of excision (removal of the clitoris) and the subsequent instruction of newly circumcised girls in the preparation of herbal remedies and brewing of pito (the local alcoholic drink), gardening, basket weaving, "how to sleep with a husband," and taboos during pregnancy and after childbirth (Knudsen 1994). The practice also had a religious significance linking women to the spiritual world, and therefore to their ancestors (Caldwell, Orubuloye, and Caldwell 1997). Indeed, according to a recent account of female circumcision in the region, "the final permission for womanhood initiation, which is based on excision, is granted from the spirit world" (Knudsen 1994:169). Thus, typically a soothsayer was present at the ceremony, which involved sacrifices of animals and foods for both the gods and the ancestors. While ritual circumcision of girls appeared to be a fundamental feature of the transition to adulthood in traditional Kassena-Nankana culture - in fact a girl was considered unmarriageable if she hadn't undergone the procedure-it is not known when the practice began. Information on the origins of circumcision elsewhere in 
sub-Saharan Africa suggests that the practice may only date from the middle of the nineteenth century (Leonard 1996).

According to these descriptions, then, circumcision for girls took place soon after the onset of menstruation, with marriage, perhaps preceded by sexual activity, following closely after. As for boys, even less is written about their transition to adulthood. According to Rattray (1932:139), "When a man has sons, he tries to teach them farming; he does not wish them to idle about; he wishes them to look after cultivation, the rearing of winged creatures, and live stock...." Modern accounts of "traditional practices" note that boys are trained by older men of the compound in the jobs of their lineage (see, for example, Abasi's (1995) discussion of his inheriting the role of bayaa, funeral or burial expert, from his father). Adolescent boys were provided with plots of land to farm for themselves and had increasing responsibility for the grazing of animals. Girls' duties, in contrast, were primarily domestic and performed near the family compound, thus effectively limiting interaction with peers other than kin. Beginning in early adolescence boys spent increasing amounts of time with age mates attending funerals and going to the market (Grindal 1982). Boys were also permitted to sit with elders when important discussions took place, although they were not allowed to participate (Fayorsey, Adongo, and Kajihara 1994). According to Naden (1974), who was writing 25 years ago, temporary migration was common. Work was sought in the southern part of the country on cocoa plantations, in mining and timber operations, and in homes as domestic servants. While the impetus for migration might have been economic, given the relative isolation of the District, this temporary movement must have had an impact on a social structure based on strong identification and cooperation with kin, com- 
pliance with authority, and respect for one's elders. Writing 30 years ago about the Sisala, Grindal (1982:67) commented: "Migration to the South thus provides a means of bypassing the traditional age-status system by allowing the young man sufficient economic autonomy to acquire the material symbols of wealth and prestige."

Little was written about adolescent male sexual activity in the past other than what we have cited earlier with regard to girls. Analyses of sexual behavior in other polygynous societies suggest that an "implicit contract" between older and younger men gave the younger men access to the junior wives of the patriarchs and made postponement of marriage more tolerable (Calvès, Cornwell, and Enyegue 1996; Orubuloye, Caldwell, and Caldwell 1991). It is unclear whether this practice existed among the Kassena-Nankana as well. Cardinall (1926) indicated that it was only older men who, by virtue of their status in the community, had access to women, even women who are not their wives. Thus, when adolescent boys had sexual intercourse, which they did with unknown prevalence and frequency, it was, he said, not entirely acceptable. "Old men will have the women, and only illicit intercourse is possible for the youth of both sexes since youth must be satisfied" (p. 76). This remark makes sense only if by "youth" Cardinall meant very young adolescents boys and uncircumcised girls. Given the dominant position of older men, who, according to Cardinall, "control the market of the women," it may have been sexual activity of young male teenagers that was viewed with disfavor. Alternatively, while the behavior may have been considered "illicit" by Cardinall, a white Christian colonial, it is not clear whether it would have been viewed that way by the Kassena-Nankana themselves.

Unlike the case for girls, the literature does not refer to particular initiation rites for adolescent males. Circumcision of boys was not performed 
in colonial times. For boys, marriage marked the end of adolescence and the beginning of adulthood (Tonah 1993; Cardinall 1926). There is no mention in the ethnographies of an acceptable age for young men to acquire a lover or marry. Assuming that the Kassena-Nankana were similar to other polygynous ethnic groups, marriage may have been delayed until the late twenties (Calvès, Cornwell, and Enyegue 1996). ${ }^{8}$ Rattray devoted considerable space to a discussion of boys courting girls too early, thus squandering gifts (tobacco, guinea fowl) which are expected to be given with each visit.

It is on account of all this that some people do not agree to their children beginning early to seek for women, or wander to a place where there are girls, because they are only wasting things. A man may tell his son all this, but still the child's ears may not hear. If the son's ears are still closed and he does not agree to leave off (his wanderings), he, the father, will swear an oath upon $\operatorname{him}(1932: 140-141)$.

In characterizing traditional nuptiality patterns in West Africa, scholars commonly mention several features. First, marriage is said to be a fluid process rather than a well-defined demographic event (Meekers 1992; Bledsoe and Pison 1994). Second, there is no universal sequence of the standard African conjugal events of prestation (sharing of drinks, kola nuts, and the like), transfer of property from the husband's to the wife's clan, initiation of sexual relations, cohabitation, and ceremony (van de Walle and Meekers 1994). Third, as a result, a "degree of disjunction between...sex, conjugality, and procreation" is permitted; in other words, "premarital" sex, or cohabitation prior to completion of formalities, is not "precluded" (Fortes 1978:23; Caldwell 1967:67). Fourth, the very nature of union formation and 
connection of offspring to the lineage means that a child's "legitimacy" is not clearly determinable and is more a consequence of male acknowledgment of paternity than of a legally or formally binding marriage (Fortes 1978; Pitshandenge 1994; Bledsoe and Pison 1994). Fifth, control over marriage rests with the kin group rather than with the individual partners and typically involves transfer of bridewealth from the man's lineage to the woman's. Sixth, polygynous unions, although by no means universal, are common, particularly in rural areas, and generally involve young women and considerably older men.

Describing nuptiality patterns in Ghana three decades ago, Caldwell (1967) observed that the majority of marriages were of the traditional form with "one or more ceremonies" and bride price. Polygynous unions were common in rural areas, with approximately 45 percent of rural men aged 15 years and older in the 1963-64 Conjugal Biographies Survey of Ghana (Caldwell 1967) reporting multiple wives, compared to about 20 percent of urban men. He noted that in the rural north, most girls married at 15 or 16 , soon after puberty. Marriage rarely interfered with schooling as only 900 of the 42,000 girls aged 15-19 residing in the Northern and Upper Regions were in school in 1960. Considerable pressure for early marriage of girls was exerted, as, according to Caldwell, "there is little place in the farming compounds of northern Ghana for an unmarried woman who has reached puberty" (1967:69).

The literature describes the procedures that were expected to be followed in choosing a wife among the Kassena and Nankana. However, we know not only from reports of the process in the District but also from other accounts of West African traditional marriage that there was much variation. 
It is useful, nonetheless, to describe what was supposed to have taken place in order to note how the process has altered. The boy would likely have met the girl at a social gathering such as a funeral or festival or at the market. He then visited the girl's parents, bringing tobacco with him. If the gift was accepted, subsequent visits followed, first with one guinea fowl and then with three or four. At one of these visits, he would bring a male friend along to reinforce his case with the girl's family. ${ }^{9}$ Additional visits would take place with salt, guinea fowls, and tobacco brought as gifts. When a sufficient number of guinea fowls had been brought, the boy would refrain from visiting and other of his male relatives would replace him. They brought hoes and additional guinea fowls until the girl's family agreed to the marriage. At that point a sacrifice was made at the ancestral shrine. ${ }^{10}$ The marriage contract was sealed after the families negotiated the brideprice (Rattray 1932). Modern accounts of traditional marriage disagree as to the number of items included in the brideprice. However, there were a number of sheep (seven appears to have been most common), an ax, and assorted other items, including hoes, smoking pipes, and a bull. These gifts were paid out over an extended period. The bull, for example, was presented (or demanded) after the woman had given birth. After the brideprice was agreed upon, the girl was brought to her husband's compound in a public procession. She was kept in the elders' room for four days while being introduced to the ancestral spirits; only on the fifth day was the bride brought to her husband's room (Fayorsey, Adongo, and Kajihara 1994; Tonah 1993).

Among the Kassena-Nankana, as best as can be determined, the transition to adulthood for a boy a few generations ago entailed a greater economic role in the household through increased responsibility in farming and 
herding, stronger identification with age mates, the possibility of a temporary move to the southern part of the country to improve his economic prospects, and the opportunity for sexual activity. While "premarital union" and very early sexual activity were unacceptable, intercourse between a young man and a circumcised girl prior to marriage was apparently condoned, particularly if it led to courtship and marriage. Among girls, in contrast, adolescence, defined as we indicated earlier as the period between the onset of secondary sex characteristics and marriage, was of short duration. Prior to puberty much of a girl's time was spent in close proximity to the compound assisting her mother and other female kin with domestic tasks, although there were opportunities to interact with males at the market and at social gatherings such as funerals. Circumcision generally took place soon after menarche and, especially if sexual activity had occurred, it was desirable for courtship and marriage to follow shortly thereafter. Courtship and marriage involved a series of prescribed rituals that often took place over a protracted period of time, entailing numerous visits of the man to the girl's family compound, and gifts and transfer of property from the groom's to the bride's family.

\section{The Changing Nature of Adolescent REPRODUCTIVE BEHAVIOR IN SUB-SAHARAN AFRICA}

Having described traditional initiation, courtship, and marriage rites in West Africa and in the Kassena-Nankana District, we now summarize the literature on adolescence in contemporary sub-Saharan Africa. This discussion provides a broader context for the quantitative and qualitative data on Kassena and Nankana adolescence to follow. 
Recent analyses of adolescent reproductive behavior in sub-Saharan Africa have pointed to a transformation in the nature of sexual activity and childbearing among the young. With an increase in urbanization and education, the social fabric is said to be breaking down and with it the traditional authority structures governing marriage and sexual behavior, as well as the familial and community support networks that eased young people's transition to adulthood (Barker and Rich 1992). The result is that some scholars have characterized the African family as being in "crisis," drawing parallels to the United States (Bradley and Weisner 1997), although others merely speak of an alteration in indigenous family forms, noting that nuptiality systems, while evolving, have retained traditional elements (Lesthaeghe et al. 1994; Meekers 1992). ${ }^{11}$

Women's age at marriage is on the rise in much of the region, a development attributed generally to the expansion in schooling for girls (Gage and Bledsoe 1994; Bledsoe and Pison 1994). However, while age at marriage has gone up, age at first cohabitation may be falling. "[A] streamlining of marriage arrangements and the emancipation of young people from the control of lineages may have led to a younger age at union in many urban contexts" (van de Walle and Meekers 1994). Indeed, what is most noteworthy, and has attracted considerable attention, is the apparent increase in unsanctioned sexual activity, and the rise in childbearing prior to marriage, particularly in urban areas ${ }^{12}$ (Bledsoe and Cohen 1993). It has been argued that adolescent boys, having greater independence from families than in the past, are more likely to make sexual demands on girls (Bledsoe and Cohen 1993), and, in turn, girls who want to continue in school have an increasing need to use their sexuality for economic gain (Bledsoe 1990; Gage and Bledsoe 1994). 
Some commentators have asserted that the "fluidity" that has always characterized the African conjugal form, making marital status so problematic to define, has simply become more pronounced with time (Bledsoe and Pison 1994). Others maintain that "premarital and extramarital liaisons have only become a way of life in the wake of colonialization and modernization" (Ocholla-Ayayo 1997). Regardless, there is widespread concern about the social, economic, and health implications of this transformation in reproductive behavior and a concomitant focus in the population community on documenting it (see, for example, Boohene et al. 1991; Calvès and Meekers 1997; Kiragu and Zabin 1993; Ocholla-Ayayo 1997). The apparent unwillingness or inability of young men to support their offspring and the emergence of HIV have made these changes in adolescent reproductive behavior particularly worrisome. The question is whether this transformation in the nature of adolescence, which has been observed in more urbanized parts of sub-Saharan Africa-rising age at marriage, increasing premarital sexual activity, and childbearing - is also characteristic of a relatively remote area such as the Kassena-Nankana District of northern Ghana.

\section{DAta Collection}

Subjects for focus groups and in-depth interviews were chosen randomly from lists generated by the Navrongo Demographic Surveillance System (NDSS). The NDSS, created in 1993 and managed by the Navrongo Health Research Centre, is a population registration system that monitors demographic dynamics in the District in order to measure the impact of community health and family planning interventions ongoing since $1994 .{ }^{13}$ The surveillance population numbers nearly 125,000 people (including approxi- 
mately 44,000 young people aged 10-24) living in an area of 1,674 square kilometers. Since July 1993, each of the 14,000 compounds within the surveillance system has been visited every 90 days; demographic events have been recorded in registers and entered in a computerized data management system (Binka et al. 1997).

While there are five zones in the NDSS, it was determined that only three of them needed to be included here in order to represent the two ethnic groups resident in the District. Central Navrongo, which contains the major town and consists of both Kassem and Nankam speakers, was selected, as were two rural areas: the West zone, which is Kassem speaking, and the East zone, which is Nankam speaking. The North and South zones were not included because of the similarities between them and Central Navrongo. One sampling cluster from each zone was then randomly chosen for inclusion. ${ }^{14}$

Fifty-one in-depth interviews were conducted with adolescents/young adults, parents/guardians of adolescents, health workers, teachers, youth leaders, and chiefs/community leaders. The procedure used for selection varied. Adolescents and young adults between the ages of 10 and 24 and parents/ guardians of adolescents were randomly selected from the NDSS, ensuring that sufficient numbers of males and females (and, for the adolescents/young adults, a range in ages) were included. Nineteen of 24 adolescents/young adults were successfully interviewed and eight of 12 parents/guardians. In addition, six health workers, four chiefs/community leaders, six youth leaders, and eight teachers were interviewed. The health workers, chiefs, and youth leaders were chosen based on knowledge of the District. To select the teachers, junior secondary (grades 7-9) and senior secondary (grades 1012) schools were randomly selected from lists of schools in the Districts; teachers were then nominated for interviews by school authorities. 
Fifteen focus groups, each with between six and 12 participants, were conducted with adolescents/young adults, teachers, students, parents/guardians, and older women ages 45-65. Except for teachers and students, focus group participants were randomly selected from the NDSS. The selection process for teachers and students was similar to the one used for interviews; schools were first randomly selected and then authorities recommended candidates for participation. Because of difficulty in locating the computer-identified adolescent participants, these groups were much more heterogeneous than is considered desirable; one focus group was conducted in each of the three zones and thus girls and boys between the ages of 10 and 24 were grouped together.

In both interviews and focus groups, respondents were asked about current initiation rites, including their opinions about circumcision for both boys and girls, sexual behavior of adolescents, the marriage process and the age at which it is socially approved to get married, mobility and migration of adolescents, and peer networks. In addition, chiefs, parents, and older women were asked about differences between adolescent behavior now and in the past, including changes in sexual behavior, age at marriage, the marriage process, and migration. In the in-depth interviews, adolescents were asked about their behavior with regard to sex, their schooling, and migration outside the District, as well as about partner selection (if married) or expectations about partner selection (if unmarried).

Responses from interviews and focus groups were analyzed by collecting all statements on a particular subject, summarizing the main point if there was consensus, noting differences if there was disagreement, and then selecting examples of typical comments for inclusion. 


\section{NDSS AND PANEL SURVEY DATA ON EDUCATION, MARRIAGE, AND ADOLESCENT FERTILITY}

Beginning in October 1993 and continuing annually, a demographic panel survey has been conducted among all women aged 15-49 in a sample of about 1,200 compounds in the Kassena-Nankana District. Starting with the second round of the panel in 1994, women's husbands have also been interviewed (Binka, Nazzar, and Phillips 1995). In what follows, we draw on data from the latest complete panel survey in 1996, as well as on NDSS data.

Table 1 shows the percentage of women who have been to school by five-year age groups as well as the percentage who have ever been to junior secondary school, thus having completed primary school. These data from the panel survey reveal that there has been a tremendous increase in educational participation in the District. Only about one-quarter of women aged 40-44 have ever been to school, compared with over two-thirds of those

Table 1 Percent of women aged 15-44 in Kassena-Nankana District who have ever been to school and who have ever been to junior secondary school, by age

\begin{tabular}{lccr}
\hline Age & $\begin{array}{c}\text { Ever been } \\
\text { to school }\end{array}$ & $\begin{array}{c}\text { Ever been to junior } \\
\text { secondary school }\end{array}$ & $\mathbf{N}$ \\
\hline $15-19$ & 68.4 & 41.2 & 645 \\
$20-24$ & 52.7 & 26.5 & 888 \\
$25-29$ & 35.8 & 14.3 & 911 \\
$30-34$ & 27.5 & 10.3 & 891 \\
$35-39$ & 24.4 & 10.7 & 794 \\
$40-44$ & 24.3 & 9.1 & 695 \\
\hline
\end{tabular}

Source: 1996 panel survey tabulations 
aged 15-19. As for enrollment in junior secondary school, the increase among younger women is even more striking. Over 40 percent of those 15-19 and over one-quarter of those 20-24 have attended junior secondary school, compared with 9-14 percent of those 25-44. Given the recent expansion in schooling, it probably is no longer accurate to characterize the District as an area where "levels of educational attainment and literacy are low" (Binka et al. 1997). Educational attainment and literacy are unquestionably low among adults; adolescents, on the other hand, have had an opportunity to go to school, and they are clearly the first generation in this District to have done so in significant numbers, although it is not known whether the schooling they have had is of sufficient quality to confer literacy.

Table 2 presents data from the panel survey on the percentage of women married by ages 18 and 20 by current age groups. Given the earlier discussion about courtship and marriage in West Africa, there is no unambiguous date at which marriage can be said to begin among women in the region. Nonetheless, the survey research team attempted to elicit this information.

Table 2 Percent of women aged 18-44 in Kassena-Nankana District who have been married by age 18 and percent of women aged 20-44 married by age 20

\begin{tabular}{lccr}
\hline Current age & $\begin{array}{c}\text { Married by } \\
\text { age 18 }\end{array}$ & $\begin{array}{c}\text { Married by } \\
\text { age 20 }\end{array}$ & N \\
\hline $18-19$ & 21.8 & & 317 \\
$20-24$ & 25.2 & 55.1 & 886 \\
$25-29$ & 27.2 & 65.3 & 911 \\
$30-34$ & 29.2 & 68.4 & 891 \\
$35-39$ & 28.1 & 68.1 & 795 \\
$40-44$ & 27.2 & 66.3 & 695 \\
\hline
\end{tabular}

Source: 1996 panel survey tabulations 
To the extent that the data reveal a trend toward later age at marriage, it is very recent in origin. About two-thirds of women 25-44 were married by age 20, compared with 55 percent of 20-24-year-olds. As for very early marriage, that is by age 18, it appears that for women 20-24 and more so for women 18-19, the prevalence is lower than in the past. While these results are not nearly as noteworthy as those on education, the increase in schooling undoubtedly presages a change in the timing of marriage and perhaps in the nature of the courtship process and of conjugal relations.

The data on adolescent and young adult fertility that are drawn from the NDSS and shown in Table 3 are somewhat puzzling. These numbers, which together with the age-specific figures for women 25-49 produce total fertility rates for the area ranging from 4.6 in 1996-97 to 5.3 in 1994-95, are low for a non-contracepting population. A comparison with the DHS rates for rural Ghana, displayed on the far right of Table 3, confirms this. An analysis of the quality of the NDSS fertility data reveals some evidence of underreporting of neonatal events that end in death. However, the estimated fertility rate is considered plausible for a population with high levels of lactational amenorrhea and lengthy postpartum abstinence due to spousal sepa-

Table 3 Age-specific fertility rates for women aged 15-24 in KassenaNankana District

1993 DHS

rates for

\begin{tabular}{lccccc} 
Age & 1993-94 & $\mathbf{1 9 9 4 - 9 5}$ & $\mathbf{1 9 9 5 - 9 6}$ & $\mathbf{1 9 9 6 - 9 7}$ & rural Ghana \\
\hline $15-19$ & 101 & 88 & 80 & 83 & 145 \\
$20-24$ & 228 & 235 & 218 & 209 & 273 \\
Total fertility rate & 5.0 & 5.3 & 4.8 & 4.6 & 6.4 \\
\hline
\end{tabular}

Sources: NDSS tabulations; Ghana Statistical Service and Macro International (1994) 
ration following childbirth (Binka et al. 1997). Moreover, the data on rates of net migration by age indicate considerable movement out of the District by young adult men for employment, suggesting that part of the explanation may also lie with a temporary (or perhaps permanent) deficit of men. In short, it appears that adolescent fertility in the District is not as high as in other pre-transition societies. However, these data do not reveal whether the nature of adolescent childbearing has altered-whether, for example, there has been an increase in premarital pregnancies and births among young women. We now turn to the qualitative data, which give us a sense of how those currently residing in the District view the experience of adolescence and, in particular, whether they perceive any changes in the lives of young people.

\section{THE ADOLESCENT EXPERIENCE IN KASSENA- NANKANA DISTRICT}

We begin our discussion with an analysis of the comments made on circumcision, followed by those made on sexual behavior and marriage. Much of this section consists of direct quotes from the transcripts in order to let our respondents speak for themselves. ${ }^{15}$ Each quotation is identified according to whether the respondent was in a focus group discussion (FGD) or participated in an in-depth interview (IDI), and by zone, age, ${ }^{16}$ and sex. Occasionally, as is indicated, it was not possible to identify the respondent.

\section{Circumcision}

As we indicated in our discussion above, female circumcision was a key feature of Kassena-Nankana ritual life, not only signaling a readiness for marriage but also permitting the fulfillment of certain rituals. For example, an uncircumcised daughter was not allowed to participate in her 
mother's funeral rites. And, according to religious beliefs, nonperformance in these rituals meant that upon her own death the woman would not be able to join her ancestors. The respondents accepted circumcision as a long-standing rite of passage for girls practiced in generations past:

As a girl, when you are circumcised, it means you have become a woman, and you can also be able to take part in performing your mother's funeral. (IDI, 87-year-old male, West Zone)

The only thing I know about it [female circumcision] is that it was practiced by our ancestors and passed down to us. That is why girls are being circumcised. (IDI, 70-year-old male, East Zone)

According to respondents, circumcision was undertaken in order to ready a girl for marriage and as a mechanism for controlling female sexuality:

People in the past thought that if a girl was of age and was not circumcised she didn't have the chance to grow well because she had unhealthy blood in her; so if she went through the practice, that blood was drained and she will develop fresh blood which will make her healthy and strong enough to marry. (IDI, 37-year-old female, East Zone)

Circumcision of females controlled their sexual attitude toward men. (IDI, 19-year-old male, West Zone)

The practice was justified on the basis of its being normative; if it was not done- and nonperformance was said to be visible because, in the past, clothing was seldom worn - the woman would be ridiculed and her babies stigmatized. 
[In] our time, there [was] no clothing to cover our "ugly faces" [vagina], so we removed the clitoris because it exposed us too much. (FGD, 54-year-old female, East Zone)

[In] our time, we had no clothes to cover our private parts and our clitoris was exposed for people to see and so we [were] circumcised. (FGD, 49-year-old female, West Zone)

Age mates and especially rivals laughed at their colleagues who were not circumcised. Such uncircumcised women were regarded as men since their clitoris resembled the male's penis. (FGD, 49year-old female, West Zone)

We circumcised because colleagues hurled insults such as "longbig-thick-clitoris" at those women who didn't circumcise. (FGD, 52-year-old female, Central Zone)

Babies born to uncircumcised women were called zankabri bia (clitoris babies) and were treated with disdain in society, as they were considered stubborn. These are things most women can't stand or take in our society. (FGD, 56-year-old female, East Zone)

There is remarkable unity among respondents in their opinions on the causes of change in patterns of circumcision, and the desirability of those changes. For the most part, informants say that female circumcision has been brought to a halt because, on the one hand, the social ostracism that enforced adherence to the custom has now faded, and, on the other, the practice is unhealthy, unnecessary, painful, and reduces sexual sensation: 
In the old days, we didn't have clothes to cover our private parts, and when we were like this...our clitoris appeared and people could see it. But now you boys and girls of today have clothes to cover yourselves and no one sees your private parts. (FGD, 53year-old female, West Zone)

...in the old days, there [were] no health facilities and during delivery the clitoris "would be spitting" at the women who are helping to labor and they would be insulting her. (FGD, 22-yearold female, West Zone)

Fewer girls are now circumcised as compared to the past because in the past if you were not circumcised your friends laughed at you. (FGD, 20-year-old female, Central Zone)

Nowadays it is not advisable to circumcise our daughters because we are all now exposed to different types of diseases and this procedure involves the flow of blood and people could easily contract disease. (FGD, 50-year-old female, Central Zone)

God knows why he put that part of a woman there and since it is not blocking any act, then it should be left there so that we all have our peace. (FGD, 48-year-old male, West Zone)

They can bleed to death in the course of circumcision. They could also get infection which would affect them later. Others can get barren due to this circumcision, through infection. (FGD, 22year-old male, Navrongo Town) 
The girls are not able to urinate when they are circumcised. (IDI, 19-year-old female, West Zone)

I don't support female circumcision because it kills their sexual feelings. (IDI, 19-year-old female, West Zone)

Interestingly, a large number of respondents who say female circumcision is unhealthy cite a particular concern: that the loss of blood caused by excision, coupled with the loss of blood during childbirth, may be too much for a woman to bear:

The practice makes girls suffer a lot because they lose a lot of blood and when they are going to deliver they lose blood again, which is too much. (FGD, 14-year-old male, East Zone)

The white man too is right to say the practice [must] be stopped, because the female...normally loses too much blood in the process, and more [than] that, the women still lose blood at childbirth. Now if the two [are] combined, [what] would the life of the woman be like? (FGD, 48-year-old male, West Zone)

Additionally, some respondents say the practice has declined because "you people" - the government and its health workers - have decided it should be stopped. Indeed, it is worth noting that the Ghanaian government outlawed female circumcision after the 1994 International Conference on Population and Development-one of the first developing countries to do so.

Female circumcision has been practiced since we were born but you people have come to stop it and rather encourage male circumcision. (FGD, 64-year-old female, East Zone) 
The government has asked for this circumcision to be stopped. (FGD, 49-year-old female, West Zone)

...for the women, since you people are saying they should not be circumcised, then I think it must be stopped. (FGD, female, West Zone, age unknown)

Interestingly, the 1995 panel survey, which included a module on female circumcision, revealed that its prevalence has declined greatly, a finding that is consistent with our qualitative results. While circumcision was nearly universal (96 percent) for women aged 45-49, it is much less common among women 15-19: only one-quarter of these young women had undergone the procedure (Adongo et al. 1998).

Male circumcision is a relatively new phenomenon in the District, and some respondents noted that it was not part of traditional culture:

I don't see any significance of boys' circumcision, it is something our ancestors never did. They copied this from other people as they travel to the south [of the country]. (IDI, 70-year-old male, East Zone)

Traditionally, a male is not supposed to circumcise because if you do you can't take part in important social sacrifices. (IDI, 20-year-old male, East Zone)

Respondents' comments about male circumcision form an almost exact mirror image of those cited above regarding female circumcision: respondents say that uncircumcised men catch and spread diseases, that the government 
promotes male circumcision, and that men willingly circumcise themselves nowadays, out of a desire to appeal to women, and to enjoy sex more fully as well as to avoid social ostracism:

You people have been saying that if a boy is not circumcised he may contract diseases.... (FGD, 56-year-old female, East Zone)

It adds beauty to itself when circumcised because it is attractive to women, it is clean, doesn't contract STDs, and detection and treatment of disease is quick. (FGD, 40-year-old male, Central Zone)

An uncircumcised [man] will not get any girl because no woman likes to have uncircumcised boyfriend or husband. (FGD, 48year-old male, West Zone)

Circumcised penis penetrates easily and makes sex exciting. (FGD, 48-year-old male, West Zone)

Those boys who have been circumcised make fun of those who haven't and so the adolescent boys see it to be very important in their lives.... (FGD, 20-year-old male, Central Zone)

A 13-year-old boy from the East Zone expresses succinctly the overall response to circumcision that emerges, remarkably consistently, from the various District residents consulted:

Girls should not be circumcised but boys should be.... Girls can die through circumcision but for boys it prevents diseases.

Occasional voices in defense of female circumcision, or unwilling to accept 
the reasons for its demise, are raised in the interviews and focus groups (especially among respondents from the East Region):

I will say it [female circumcision] should be continued because it is an ancestral practice which was passed down by our forefathers. It is because most young girls now go to school and because they cannot endure pain that they do not do it anymore. (FGD, 41-year-old male, East Zone)

What she has said is really true; circumcision of females is an ancestral practice. So why should it be stopped?...The only thing is that you cannot force who doesn't want to do it. (FGD, female, East Zone, age unknown)

...the only thing we want is to allow us to continue with our female circumcision, that is all I have to say. (FGD, 51-year-old female, East Zone)

It is because the girls are afraid of the pain, that is why they want to tell the whole world that it leads to anemia [and] complications during birth ... so...today, they don't circumcise, yet they are still anemic...others say circumcision reduce[s] fertility. People [were] circumcised, yet they gave birth to [as] many as ten children. (FGD, 52-year-old female, Central Zone)

\section{Sexual Activity}

The perceived rise in premarital sexual activity in the District is associated in the minds of many informants with the decline in female circumci- 
sion. Several adults say that the discouragement of female circumcision has led to a situation in which girls' developmental status is unclear and their sexual desire uncurbed; unsanctioned sex is thus more likely:

The cause of this [earlier] marriage among the adolescent boys and girls is because the girls do not circumcise... and when their clitoris erects then they feel like having sex. They enjoy sex such that they marry earlier. (FGD, female parent, West Zone, age unknown)

[In] our time, one only started moving with boys after you were circumcised, but nowadays, as this idea of circumcision has been stopped, [as soon as] the girls start shooting breast they feel they are grown so they start "jumping on boys." (IDI, 50-year-old female, East Zone)

In the past, a girl's maturity was determined by her time of circumcision. If a girl was circumcised you knew she was matured enough to relate with the opposite sex. Circumcision is no more practiced so it is difficult to have any control over the boys and the girls. (FGD, 51-year-old female, East Zone)

...girls are now granted freedom as they no longer undergo any initiation rites-like female circumcision-and so they indulge in sex at a very early age. (IDI, Chief ${ }^{17}$ )

As you know [in] our time, one had to circumcise before one could start moving with men. But these days, the girls do not 
even circumcise anymore, so they start doing whatever they like at anytime. (IDI, 36-year-old female, East Zone)

While adolescents were not forthcoming about the changing nature of sexual behavior, one girl did talk about the increasing pressure on girls to have sex:

[Sex] has become a part of life, believed to be what builds your love, that is why I have been forced to do it. (FGD, 19-year-old female, Central Zone)

The adults of the community were clearly disturbed by what they felt to be changes in adolescent behavior:

The young people of today start it [sex] earlier because in the past, a boy could not relate with a girl unless she is about 16 years and above. (IDI, 87-year-old male, East Zone)

At 15 years a boy already has a girlfriend. They start drinking very young and not only pito [local beer] but even akpeteshie [local gin]....The youth of today have very bad sexual behavior...they go about flirting and impregnating girls and producing illegitimate children everywhere. (IDI, 95-year-old male, East Zone)

Even in front of you these adolescents have sex and when you want to talk they would insult you and tell you that it is none of your business. Even when you try to tell them that it was not done in the past, they would tell you that they are not in the past. (IDI, 25-year-old female, Central Zone) 
The most common reason offered by adults for the changing sexual behavior of young people is one that would probably be familiar to parents in most regions of the world. To parents and elders in northeast Ghana, things just seem, somewhat mysteriously, to have changed: children have lost respect for their parents and are behaving in ways that break radically with the values and traditions that older generations held dear:

The children today do not respect their elders. (IDI, 87-year-old male, West Zone)

When you call a child to advise him, he comes to you with a stick of cigarette between his fingers to show you he knows more than you do. (FGD, 43-year-old male, East Zone)

In the past, we used to stay at home and help our mothers, and even if you wanted to go out, you had to finish all your house duties before you could go out, otherwise you will receive some punishment. Nowadays boys and girls start boy-girl relationship rather too early that they do not even regard their parent anymore; so a girl wakes up, does not do anything, and she is on the streets roaming with boys. (IDI, 50-year-old female, East Zone)

I think the cause is disrespect. The [girls] do not respect their mothers as those who [have] given birth to them; a girl could be going out in the night and when the mother calls her she would respond that the mother is disturbing her and walk out on her mother. (FGD, 63-year-old female, West Zone) 
The youth of today are always doing what they feel is right for them. Girls do not sit at home, and the boys are even worse. (FGD, 53-year-old female, East Zone)

[Girls] will not even "shoot breasts" before they start with men. And the boys too, they will not grow and they are with women. You will advise them, but they won't take your advice, so what will you do? (FGD, 51-year-old female, Central Zone)

In the past the youth were easily frightened; if you tell them [if] they do something they will be sick, they won't do it. Today children do not fear anything. (IDI, Chief)

Sometimes, older people express confusion as to the reasons for changes in the young:

We have always tried hard but have not been able to get an answer to why this sudden changing trend. (FGD, 52-year-old male, East Zone)

We can't actually tell what the children are up to. (FGD, 41year-old female, West Zone)

We also don't know why some children do not respect their parents. Some of them beat their mothers and fathers without any cause. We do not know where these, our adolescent children, had these behaviors from. You just can't control the children. (FGD, 49-year-old female, West Zone) 
Times have changed, and everything has changed with it. ${ }^{18}$ (IDI, 70-year-old male, East Zone)

When they go beyond simple statements that today's young people will not listen to their parents and insist on breaking with tradition, elders in the sample most frequently locate the causes for such changed behavior in a set of factors that we might variously term "modernization," "the introduction of market forces," or "Westernization." Foremost among these factors, according to many respondents, is the introduction of money into what was, until recently, largely a subsistence economy. The presence of money, elders feel, has undermined their ability to discipline young people and has caused adolescents to be tempted in ways that are hard to resist:

The reason why we can no more control the children is that there is money everywhere. (FGD, 50-year-old female, East Zone)

All these early marriages are caused by the money in the system. Now when you try to control a boy, he walks out and goes to work for money. (FGD, 48-year-old male, West Zone)

In the past, food was what was used to punish children who disobeyed their parents. When a child disobeyed the mother she would cook and would not serve him. But nowadays things have changed, and when a child is refused food, that child would go outside and look for work to do in order to get money to buy food...so this discipline is not effective to these boys. (FGD, female, West Zone, age unknown) 
This complaint-that food deprivation was once an important means of discipline, but that the money economy and availability of alternate food sources has rendered it ineffective-is repeated again and again by older informants:

Everything is done in the market outside home. (IDI, 70-yearold male, East Zone)

In the past when...money was very scarce it was hard for a young adolescent to get money so you relied on your parents. But today [a child]....can go to the market and work and get money...so we really don't know what to do to the youth. (FGD, 51-year-old female, East Zone)

And some parents too have lost control over their wards because of poverty; the children do what they like, because he cannot cater for all of them. And this makes the children to be inadequate. (IDI, school master, 40-year-old male)

Beyond money itself, elders feel that the modern world has introduced young people to a dizzying array of costly material goods, and that the desire for these goods leads to disrespect and to new and unsanctioned sexual behaviors. For example, many respondents speak of chewing gum as a symbol of "the good life"- something that boys can offer girls to lure them into sexual relations.

Today you see a child in school, and he already wants a bicycle to be riding to school, jeans and other expensive clothing to wear 
at home.... [E]ven they want you to give them money to go out and spend with girls. It is not like our time when we agreed to eat sorghum. (FGD, 41-year-old male, East Zone)

The children have something they called "walk-man," which they put in the ears. They bring this thing home and try to challenge their parents. The white men manufacture so many different things, which when these children have them they do not listen to us. (FGD, 52-year-old male, West Zone)

Some of these girls need perfume, soaps to bathe, so that they would feel they are the best in the area; and it is when they cannot afford to buy the soap that brings about such [sexual] behavior. (FGD, 51-year-old female, West Zone)

...some of them, immediately you finish advising her on [sexuality], she would bypass you and go to the market. Now if she is in the market and a boy buys her chewing gum, before you would realize, they have moved into one of the rooms in the market and have their sex. (FGD, 63-year-old female, West Zone)

Furthermore, many elders seem to feel that these new temptations of money and material goods are particularly difficult for parents and youth to cope with in the context of a depressed economy with few job prospects:
A boy may live with his father, and the father doesn't even have a fowl which he can sell to help him. (FGD, 41-year-old male, East Zone) 
I also feel that it is because these adolescent boys don't have employment, that is why they have time to think about bad things. (FGD, 37-year-old male, Central Zone)

As I said earlier, what [young people] want and think about is money, and the government cannot get employment for them. (IDI, Chief)

The most disturbing problem is employment; when [adolescents] are employed they will not engage in social vices. (FGD, 52year-old female, Central Zone)

Young people emphasize the role of poverty in their lives even more than their elders do-particularly how poverty and new desires together (rather than simply the desires themselves) push young people (especially girls) toward sex, and away from traditional forms of marriage:

All of these behaviors are caused by lack of money in the hands of our parents. If our parents had money for our sisters to buy their needs, that would let them limit their sexual behaviors toward men. (FGD, 24-year-old male, West Zone)

This sometimes happens in our schools, especially [to] those from poor backgrounds. When they come to school and they see their friend having a nice thing, they also want to possess those things, and by so doing they get involved [with] rich people to get these things. (FGD, 18-year-old female, Navrongo Town) 
In the past, girls did not move about as much as boys, but nowadays, when they see their friends with nice dresses, they want to have some, and since their parents cannot afford [them] they move about even more than the boys in search of these things. (FGD, 19-year-old female, East Zone)

Sometimes some want to give money to their girl friends though they do not do any work to earn money, so they are forced to steal.... Some girls move with boys because they buy them...chewing gum. (FGD, 20-year-old male, East Zone)

A teacher confirms that sex is exchanged for money or gifts in this society:

[Girls] are always thinking of what they will get from [boys] and... a boy [is] always thinking of how to get money to buy sweets for the girl. (FGD, teacher, 40-year-old female)

Respondents attribute the emergence of sugar daddies - older men who give girls presents or pay for school fees in exchange for sex-and prostitution to rising levels of poverty:

In the old days, parents gave their children food. Today, we can't provide them with their food requirements. Hence, when she comes in and you ask her to fetch you water, she will ask you if you gave her food to eat before they left for school. So this girl will go back to the boy or man who gives her money to buy food, and anything happens there. (FGD, 52-year-old female, West Zone) 
Day in, day out, you see cars, motorists, and even bicycles coming. They are elderly people, and they come to send our girls away. You know very well they send them out for a very good pasporse [sex]. Because if an old man sends you to a beer bar, you won't drink and go free. After the chilling, you will have to go somewhere else and also have a nice time with him. (FGD, 22-year-old male, Navrongo Town)

This sugar daddy is giving society a whole hell of problem. Instead of them using their money to educate their own children, they use it to spoil others' children. (FGD, 20-year-old male, Navrongo Town)

There are adolescent girls who are not married but cross the border to Burkina Faso, where they live immoral lives of prostitution and come back with diseases; most of these die with AIDS. (IDI, Chief)

Another sometimes-cited source for new and disruptive ideas, especially about sex, is the modern media, including films and videos:

It is when the children attend film shows and video that they get into...sex. (FGD, 38-year-old female, West Zone)

We are at this state because there is all sorts of entertainment around us. So children don't sit with their parents to learn from them through storytelling. So, why won't they go wayward? (FGD, 52-year-old female, Central Zone) 
Sometimes you realize that the media has influence on these adolescents; when they go to watch films or look at pictures they try to experiment....(IDI, school master, 57-year-old male)

Some adults state categorically that the introduction of European-or "white"-values has eroded traditional norms and caused new behavior in children:

It is the white man who has spoiled our children and not us. (FGD, 52-year-old male, West Zone)

[W]e are copying the life style of the white man. We wear their clothes and do everything that they do, and so definitely we should also take to their behaviors. (FGD, parent, Central Zone, age and gender unknown)

[In] our time, when you saw a girl and were interested in her, you send kola nuts and tobacco to her father to declare your intention. But nowadays, you people do not do that; you've taken the white man's ways. (IDI, 70-year-old male, East Zone)

It is the coming of the white man that has caused [premarital childbearing]. (IDI, Chief)

European culture has come in to destroy our culture; children do not respect their parents, they go about smoking [marijuana] ....(IDI, Chief)

Other adults mention drugs and alcohol as problems in teens' lives-although a connection between substance abuse and changing sexual patterns is not always made: 
These adolescents sometimes stick to drinking alcohol, smoking wee [marijuana], and taking all sorts of drugs which they shouldn't have done. (IDI, 25-year-old female, Central Zone)

[Young people] will only use [wages] to drink, because that is the youth's priority. (IDI, Chief)

Because most of these boys don't attend school, they indulge themselves in drugs, drinking, and smoking. (IDI, Chief)

Occasionally, adults seem willing to admit that poor parenting-including drinking and drug abuse by fathers - may lead to undesirable sexual behavior among youth:

It is when a parent tries to dictate to his daughter that she goes about with so many boys, because the choice that you the parent have made would not suit your daughter. (FGD, 38-year-old male, Central Zone)

To me, there are still obedient children among the youth; depending on the way you train your child, he can be a very responsible child....[S]o for me it is how you train or bring up a child that makes him or her what he or she is. (FGD, female, East Zone, age unknown)

Some parents are so irresponsible that to the children, it would have even been better had their parents died because they only drink and drink and forget the children. (IDI, Chief)

Young people - not surprisingly - are much readier than their parents to emphasize the role of bad parenting in the changes going on in their lives: 
I don't actually know how exactly [my family feels] about my education, because sometimes...after writing your final exams, nobody would bother to find out from you about your performance, and this sometimes makes us feel that we are just burdens on people. (IDI, 19-year-old male, West Zone)

Some fathers, too, even when their daughters come home very late from the market, they do not bother to question them to know why they have kept so long in the market, and if this is always done it would help to check the children not to misbehave outside their homes. (FGD, 16-year-old male, West Zone)

And a mother or father who sees a boy with a girl friend, instead of calling the boy and sit him down with the girls and advise them, they rather throw insults at them, try to prevent them. And you see, when you do that, they will hide and see each other at a place which is not very appropriate. So, they should reason with the adolescents, and counsel.... (FGD, 18-year-old male, Navrongo Town)

Furthermore, young people often state that they would welcome a firmer hand and greater discipline from their elders: ${ }^{19}$

If we are allowed to move freely and do what we want, we cause trouble not only for the school but for our parents as well; some will...like to go to town and drink, and if you are allowed to go, he will go and do something worse than that. So, I think we should be controlled. (FGD, 17-year-old male, Navrongo Town) 
As adolescents, when we stay out too late it will be good for our parents to warn or even beat us to correct us.... (FGD, 17-yearold female, East Zone)

I think [sexuality] should be controlled, and even there should have been a kind of laid-down procedure that one should go through before one can be able to relate with the opposite sex. (FGD, 20-year-old male, Central Zone)

Young people cite negative peer influences as a source of changed or "bad" behavior much more often than do elders:

It happens at the secondary school, by the influence of...fellow students. If one lives in a remote area and... [t]hen he or she goes to the secondary schools and meets friends who happened to have had sex...this...would influence [one] to also indulge in such things. (FGD, 18-year-old male, Navrongo Town)

I think we are being introduced to some of these [sexual] things through peer groups. There are bad friends, and there are good friends. (FGD, 18-year-old male, Navrongo Town)

When you move with bad friends, they could influence you to do things that you should not have done, and this can affect you greatly in future. (FGD, 21-year-old male, Central Zone)

Teachers and headmasters/mistresses share adolescents' views that parents and negative peer group influences bear a large share of the responsibility for new behavior among youth: 
...what may cause the dropout is lack of parental care. This is where the girls may be induced to fall to love affairs with some people and may get pregnant and finally drop out. (IDI, school master, 57-year-old male)

[Adolescents' problems] may also be due to parental neglect and peer group influence. (IDI, school master, 46-year-old male)

Some of them engage in activities that do not promote learning-for instance, joining bad groups. (IDI, school master, 37year-old female)

A few elders seem to feel that the introduction of family planning has made unsanctioned sex more likely by eliminating penalties for sexual behavior:

Now it is family planning which has brought about all these behaviors; it used not to be like this in the past, because when one girl became pregnant, the other learned from her mistake and feared to go near men. (FGD, 41-year-old female, West Zone)

It is the condom that causes everything. If there is no condom and she goes out, [she] contract[s] STDs.... The next time she sees a penis erected, she will be afraid to go near it. But the condom protects them, hence the misbehavior. (FGD, 52-yearold female, Central Zone)

The government nowadays have brought so many medicines for the prevention of pregnancies, and that is why when you advise these adolescent girls, they do not listen. They feel they can never get pregnant. (FGD, 49-year-old female, West Zone) 
Young people also attributed the increase in sexual activity to the introduction of family planning:

This introduction of family planning....You just see a small girl, she is not up to the age to have sex, but through this introduction she has got the chance of doing, having sex, doing whatever she wants. (FGD, 23-year-old female, Navrongo Town)

And, finally, schools are mentioned both by parents and teachers as possible catalysts of changed behavior in the young:

Times have changed and things are not as they used to be with education now. The children seem to feel that they know better than their parents so they will not take what they tell them. (FGD, female, East Zone, age unknown)

Nowadays, caning is disallowed in schools and that used to be the measure they used in disciplining the students. But now that it is not allowed, what measure are you going to adopt to help him, because sending the child home on suspension would mean nothing to him now that they are not interested in learning. (IDI, school master, 40-year-old male)

...in school, [students] do things together and form study groups and these can lead them to have interest in one another and eventually turn to something else [sexual]. (IDI, school master, 57year-old male)

To summarize, parents and older people in the Kassena-Nankana District tend to trace changes in their children's sexual behavior to invasive 
forces-money, media, "white men's values," family planning-that have contributed to a general breakdown in behavioral norms and values to produce a new, troubling, and somewhat incomprehensible sexual status quo. Younger people recognize many of these same factors, but with a subtle difference: while elders see the invasive forces as the problem, youth are more likely to take these forces for granted, and to locate the problem in their inability to respond effectively to them. Thus, whereas an older person may see a desire for consumer goods as the problem, a younger one might see the difficulty as poverty and the attendant inability to acquire consumer goods. Whereas an older person may blame the problems of young people on the unbridled search for gratification, an adolescent might blame parents' failure to help young people negotiate the many temptations that confront them.

\section{Premarital Pregnancy and Abortion}

Considerable concern is expressed about the consequences of unsanctioned sexual activity. Respondents talk about rising levels of premarital pregnancy and about abortion, which, while legal in Ghana, ${ }^{20}$ is not readily available:

My son impregnated a girl and we asked [him] to marry her. $\mathrm{He}$ refused and we ignored him, performed the marriage rites and brought the girl to the house. He traveled and never asked the girl should follow up and now the girl is married to another man. (IDI, 60-year-old male, Central Zone)

Nowadays, you find a girl who is not married but has a child already; this was not the case in the past. (IDI, Chief) 
Almost every day girls are causing abortion everywhere; they only give birth when the abortion fails; I have clear examples here in my house. (IDI, Traditional Leader)

Most girls abort such pregnancies; it is only when they are not successful that they give birth. (IDI, 50-year-old female, East Zone)

Some of these pregnancies before you realize they have disappeared. Ask what happens to the pregnancy, they will ask you whether you are the one who impregnated her. (FGD, 56-yearold female, East Zone)

When pregnancy occurs, she would not tell you but rather go to her boyfriend who is the cause of the pregnancy to see what they can do to abort it. (FGD, 63-year-old female, West Zone)

\section{Care of Illegitimate Children}

There is disagreement about who is responsible for the care and cost of children born out of wedlock, the woman's family or the man's, suggesting that this phenomenon is of such recent origin that societal norms have not yet emerged about how to deal with it:

Some of the girls ... do not stick to one partner; so when there is any pregnancy the boy ... may refuse to accept the pregnancy because he feels he didn't impregnate the girl alone. When this happens the girl's father is forced to accept the girl and her child. (FGD, 24-year-old male, West Zone) 
In the past, such a child was owned by the girl's parents; but nowadays parents see such children as a burden, so the child is usually given to the boy. (FGD, 21-year-old male, Central Zone)

If the boy who is responsible refuses to take the girl and the child, then it becomes the girl's parents' burden, because no other person will claim responsibility. (FGD, 19-year-old male, East Zone)

It is the parents who would be responsible for all the health of the child, feeding and clothing of it. This is because you accepted your child with her pregnancy; so anything about her is now unto you. (FGD, 58-year-old female, West Zone)

It is the boy or man who impregnated her who owns the child. I am saying this because even if the boy refuses to accept the pregnancy, the child will by all means look for and go to his father when he grows. (IDI, Traditional Leader).

Usually it is a man who owns a child, but nowadays when a boy impregnates a girl he usually denies it, so it ends up being a burden for the girl's parents. (FGD, 20-year-old male, Central Zone)

\section{Marriage and Courtship}

The elders in the community believe that the ease of access to sexual partners has reduced the incentive to marry:

In our time, they used to marry because of sex and children. But these days they don't need to marry; after all they can have their sex 
all right. If they release their sexual tension, what else? The children? They don't want. (FGD, 52-year-old woman, Central Zone)

These days you can't force your son to marry because he gets his sex all right. The women will always come to him, and if you marry a woman for him, he will run away and leave her for you. What will you do with her? (FGD, 52-year-old female, Central Zone)

In the past, even if you didn't want to marry, your parents could force and give you to a husband. But now if a parent does that, the girl will not even stay. (IDI, 50-year-old female, East Zone)

The traditional marriage process is apparently being bypassed; parents and families are less involved than in previous generations. Respondents commented on courtship in earlier times, and some compared it to the present:

In the past, if a boy saw a girl whom he would like to marry, he informed his father. It is the duty of the father to go about asking people about the conduct of the girl and if he found her suitable, then he made the necessary arrangements for the marriage to take place. (IDI, 53-year-old male, West Zone)

In the past, when a boy saw a girl he wanted to marry, he would have to see the girl's parents and ask them to permit him to marry their daughter; if they agreed, they would ask him to go ahead and perform the marriage rites. (IDI, 38-year-old female, West Zone)

In the past, before a boy could get married to a girl, he had to see the parents of the girl with kola nuts to let them know his inten- 
tion. This continued until such a time that the parents of the girl were satisfied, and they would release the girl for him to marry. (IDI, 38-year-old female, West Zone)

What these young boys do nowadays is they bring their girlfriends to the house, and after some few weeks these girls become pregnant; they then ask their mothers to make a shrill noise to indicate that the boy has married. After the shrill noise has been made, it is then the duty of the father to fight things out with the in-laws because his son did not pass through the right channel to marry their daughter. (FGD, 40-year-old male, Central Zone)

Nowadays, if a boy sees a girl he is interested in, he does not even take the pain to inform his parents about it but goes ahead to marry the girl. (FGD, 20-year-old male, Central Zone)

Nowadays, the children don't live like husbands and wives. Also, in the olden days, our husbands didn't marry us in the way the modern boys and girls marry. They pack and stay together without any marriage rites being performed; so they live as boyfriends and girlfriends. There is no respect in such marriage. (FGD, 62year-old female, West Zone)

Now the youth are their own parents when it comes to sex and marriage. A girl no more bring her boyfriend to the house to show to her parents. The kola [nuts], guinea fowls, etc., are collected...in the market in the form of money and kind. (FGD, 56-year-old female, East Zone) 
There is even a suggestion that courtship has become a considerable financial burden. Lack of economic opportunity is mentioned as a bar to following traditional marriage rites and hence, by implication, an impetus to nontraditional coupling:

The marriage process should be changed because it involves a lot, and usually after doing all these things there may be no money left to take care of the woman, and this brings problems in the marriage. This is even one of the reasons why young men can't marry nowadays. (FGD, 21-year-old male, Central Zone)

The items of marriage should be reduced so that a lot of young boys will be able to get wives to marry. (FGD, 21-year-old female, Central Zone)

Today, the boys and girls do not follow this procedure because they are lazy to work and get money; they face the problem of finance to go about the marriage rites. (FGD, 38-year-old female, West Zone)

I think they just do not want to marry for their own reasons, and for the boys it is sometimes due to poverty — when they marry it is a problem to be able to get the items needed for the dowry and also to take care of the woman. (IDI, 50-year-old female, East Zone)

\section{CONCLUSION}

Researchers who have investigated the reproductive behavior of adolescents in contemporary sub-Saharan Africa argue that a fundamental trans- 
formation has taken place in the lives of young people in recent years. Education and age at marriage for women are increasing and adolescent fertility is falling. On the other hand, sexual activity and childbearing prior to marriage are becoming more common. Adolescents are said to have much more autonomy than in the past, and parental involvement in everyday life, including the courtship process, has apparently declined. With the reduction in the influence of elders, the increased mobility of girls, and the undermining of the traditional mate selection process, boys are believed to be freer to make sexual demands on girls (Bledsoe and Cohen 1993).

It has been argued that the alteration in the context of adolescent fertility, in which out-of-wedlock births are a prominent feature, is primarily an urban phenomenon. Our qualitative investigation of adolescent reproductive behavior in a rural, relatively remote area of northern Ghana suggests that the behaviors that have been observed in more developed regions of sub-Saharan Africa are also being seen in isolated and poorer locales. Despite the characterization of the Kassena-Nankana District as one in which a "climate of traditionalism" exists (Binka, Nazzar, and Phillips 1995) and where "premarital fertility is low" (Nazzar et al. 1995), the social environment faced by adolescents and the reproductive behavior exhibited by them are beginning to change. While we need to be cautious in asserting that adolescent life in the Kassena-Nankana District has been fundamentally transformed in recent years-indeed, we lack longitudinal data to assess the amount of change that has taken place - this investigation has revealed that the social environment faced by young people does seem to be different than in the past. The very nature of adolescent marital and reproductive behavior has altered. Parents, adolescents, teachers, and traditional leaders talk about a 
decline in female circumcision, a rise in premarital sexual activity linked to the decline in circumcision, and a circumventing of traditional courtship. The increasing monetization of the economy and the introduction of Western television and video have apparently undermined the traditional parentchild relationship. As a reflection of the changes taking place in the District, the quantitative data on women's schooling are particularly striking. Educational attainment has risen rapidly. Moreover, this rise is of relatively recent origin, indicating that adolescent girls are fundamentally different from their elders.

Given the qualitative and quantitative evidence presented, it should come as no surprise that the physician in charge of the largest hospital in the region speaks of performing increasing numbers of abortions on school girls. The District, despite its location, is not immune to the reproductive health problems that are confronting adolescents in other parts of sub-Saharan Africa. However, given the distance from a major urban setting, and the low level of local infrastructure, the obstacles faced by policymakers and program managers in effecting change in the District are profound. The Navrongo Community Health and Family Planning Project, a large-scale intervention to introduce family planning in the District through doorstep outreach and community volunteerism, has explicitly utilized the "cultural resources of a traditional African society" in its design. The concern has been to address the social, familial, and psychological costs of using contraception among married women of reproductive age. Not only are the costs different for unmarried adolescent girls and boys, but the information, services, and other social programs needed appear to be quite distinct. With this in mind, staff at the Navrongo Health Research Centre plan to devote more attention and resources to adolescent programs and research. 


\section{Notes}

1. When the interval between menarche and marriage is short or even nonexistent, observers have talked of an absence of adolescence for girls (Whiting, Burbank, and Ratner 1986). Another view is that adolescence does not necessarily end with marriage or childbearing, but that marrying or bearing a child during the teen years affects the quality of adolescence (Mensch, Bruce, and Greene 1998).

2. Interestingly, particularly given the important role chiefs play, it was the British colonial administration through its policy of indirect rule that established the institution of chieftancy after the turn of the century (Fayorsey, Adongo, and Kajihara 1994). The region was "traditionally acephalous in political structure" (Naden 1974:35).

3. Alexandra Wilson, an anthropologist who has lived in Northern Ghana among another ethnic group and is familiar with the anthropological literature about the area, has argued that the Kassena and Nankana are sufficiently different that they should not be combined for purposes of analysis (Wilson 1998). While we have no way of evaluating her assertion, given that recent studies and interventions have regarded the two groups as similar enough to justify aggregation (Adongo et al. 1997; Nazzar et al. 1995; Tonah 1993), we have combined the two groups here.

4. The two districts to which Cardinall is referring are Navarro, the original name of the Navrongo area, and Zuaragu, which is in Bolgatonga, the district contiguous to Kassena-Nankana. 
5. Grindal's field work took place in the late 1960s, and the first edition of his research was published in 1972.

6. The Ashanti Hinterland referred to the Northern Territories of the Gold Coast (colonial Ghana).

7. Rattray was affiliated with the Gold Coast Political Service. The purpose of his 600-page book was "to furnish data which will assist those in authority to build up a sound Native Administration... which will be a model to other territories" (1932:xxi). He used an educated Nankan informer, who recorded social customs and rituals in considerable detail and then translated them into English.

8. This assertion about a late age of male marriage is purely speculative. Indeed, contemporary accounts of the transition to adulthood in the District and in a contiguous area suggest that boys marry at around age 18 (Grindal 1982; Fayorsey, Adongo, and Kajihara 1994). Whether men's age at marriage is earlier than in the past, or whether marriage may have been earlier in the past than the current demographic literature suggests, is not known.

9. A traditional saying is associated with this aspect of the courtship process: "The red ants say that number makes for strength" (Rattray 1932:145).

10. Cardinall (1926) mentioned two other ways for a marriage to take place: 1) A married woman, after visiting her natal village, would bring back a sister to assist with the housework. The sister would then be re- 
garded as a new wife. 2) A girl might be captured by the men of a compound and kept as a prisoner of the compound's women. Gifts would be given to the girl to induce her to marry. Even if the girl consented, if her parents opposed the match she was returned to them.

11. The weakening of some cultural traditions associated with the African family would not be viewed universally with disfavor. For example, the Kikuyu in Kenya have experienced an "abandonment" of initiation rites, a substantial decline in polygyny, and a reduction in brideprice. With the premium put on education, reversals in wealth transfers from the bride's family to the groom's family have even occurred in the form of assistance with payment of school fees (Worthman and Whiting 1987). In no sense, however, are these changes ubiquitous or always in the same direction. In Iboland in Nigeria, bridewealth has apparently increased, leading to a delay in marriage (Isiugo-Abanihe 1994).

12. On the other hand, adolescent fertility as a whole has begun to fall in a number of countries, although childbearing among teenagers is still higher than in any other region of the world.

13. In 1994-95, a micro-pilot service delivery study was conducted to assess the community response to the introduction of family planning services. In 1996, a four-cell factorial experiment with varying configurations of services and staff was begun in the District to test the demographic impact of family planning. In addition, a fifth cell in a contiguous district is designated as a control area. (Binka, Nazzar, and Phillips 1995).

14. Each cluster has between 35 and 99 compounds. 
15. We have quoted verbatim from translations of the transcripts. Some of the phrases are awkwardly constructed, largely because of problems in translation.

16. While most respondents gave an age, the accuracy of the responses is questionable, particularly for the older respondents.

17. To preserve confidentiality, the identifying information (age and region) for chiefs and community leaders has been omitted.

18. This phrase appears, practically verbatim, at several other points in the transcripts. Perhaps it is a local proverb or saying.

19. Adolescent and student focus groups were asked directly whether or not they should be more "controlled"; thus, young people probably indicate a greater desire to be disciplined than they would have if they had been asked a less leading question.

20. Abortion is permitted in Ghana to "protect a woman's physical or mental health, as well as on judicial and fetal impairment grounds" (Rahman, Katzive, and Henshaw 1998:60).

\section{References}

Abasi, Augustine Kututera. 1995. "Lua-Lia, the 'fresh funeral': Founding a house for the deceased among the Kassena of north-east Ghana," Africa 65, no. 3: 448-475.

Adongo, Philip B. et al. 1997. "Cultural factors constraining the introduction of family planning among the Kassena-Nankana of northern Ghana," Social Science and Medicine 45, no. 12: 1789-1804. 
Adongo, Philip B., Patricia Akweongo, Fred N. Binka, and Cheikh Mbacké. 1998. "Female genital mutilation: Socio-cultural factors that influence the practice in the Kassena-Nankana District." Poster session presented at the Annual Meeting of the Population Association of America, 2-4 April, Chicago.

Adongo, Philip B., James F. Phillips, and Fred N. Binka. 1998. "The influence of traditional religion on fertility regulation among the KassenaNankana of northern Ghana," Studies in Family Planning 29, no. 1: $23-40$.

Agulah, Bawa A., Patricia Akweongo, and James F. Phillips. 1998. “Women's fears and men's anxieties: Understanding and managing the social impact of family planning in northern Ghana." Paper presented at the Annual Meeting of the Population Association of America, 2-4 April, Chicago.

Balmer, D. H. 1994. The Phenomenon of Adolescence: An Ethnographic Inquiry. Naressa Monograph No. 4. Nairobi: University of Nairobi, Department of Psychology.

Barker, Gary Knaul and Susan Rich. 1992. "Influences on adolescent sexuality in Nigeria and Kenya: Findings from recent focus-group discussions," Studies in Family Planning 23, no. 3: 199-210.

Binka, Fred N., Alex Nazzar, and James F. Phillips. 1995. "The Navrongo Community Health and Family Planning Project," Studies in Family Planning 26, no. 3: 121-139.

Binka, Fred N. et al. 1997. "Assessing population dynamics in a rural African society: The Navrongo demographic surveillance system." Paper presented at the $23^{\text {rd }}$ IUSSP General Population Conference, 11-17 October, Beijing.

Bledsoe, Caroline H. 1990. "School fees and the marriage process for Mende girls in Sierra Leone," in Peggy Reeves Sanday and Ruth Gallagher Goodenough (eds.), New Directions in the Anthropology of Gender, pp. 283-309. Philadelphia: University of Pennsylvania. 
Bledsoe, Caroline H. and Barney Cohen. 1993. Social Dynamics of Adolescent Fertility in Sub-Saharan Africa. Washington, DC: National Academy Press.

Bledsoe, Caroline H. and Gilles Pison (eds.). 1994. Nuptiality in Sub-Saharan Africa: Contemporary Anthropological and Demographic Perspectives. Oxford: Clarendon Press.

Boohene, Esther et al. 1991. "Fertility and contraceptive use among young adults in Harare, Zimbabwe," Studies in Family Planning 22, no. 4: 264-271.

Bradley, Candice and Thomas S. Weisner. 1997. "Introduction: Crisis in the African family," in Thomas S. Weisner, Candice Bradley, and Philip L. Kilbride (eds.), African Families and the Crisis of Social Change, pp. xxi-xxxii. Westport, CT: Bergin \& Garvey.

Caldwell, John C. 1967. "Population: General characteristics," in W. Birmingham, I. Neustadt, and E. N. Omaboe (eds.), A Study of Contemporary Ghana, Volume 2: Some Aspects of Social Structure, pp. 1777. Evanston, IL: Northwestern University Press.

Caldwell, John C., I. O. Orubuloye, and Pat Caldwell. 1997. "Male and female circumcision in Africa from a regional to a specific Nigerian examination," Social Science and Medicine 44, no. 8: 1181-1193.

Calvès, Anne-Emmanuèle, Gretchen T. Cornwell, and Parfait Eloundou Enyegue. 1996. "Adolescent sexual activity in sub-Saharan Africa: Do men have the same strategies and motivations as women?" Population Research Institute Working Papers in African Demography No. AD9604. University Park, PA: Pennsylvania State University.

Calvès, Anne-Emmanuèle and Dominique Meekers. 1997. "Gender differentials in premarital sex, condom use, and abortion: A case study of Yaoundé, Cameroon." Paper presented at the $23^{\text {rd }}$ IUSSP General Population Conference, 11-17 October, Beijing. 
Cardinall, A. W. 1926. The Natives of the Northern Territories of the Gold Coast: Their Customs, Religion and Folklore. London: George Routledge \& Sons, and New York: E. P. Dutton.

Fayorsey, Clara Korkor, Philip B. Adongo, and Beverly Kajihara. 1994. "Findings and recommendations on the social organization in KassenaNankana District: Assessing the contexts for reproductive change in a traditional African society." Unpublished report submitted to the Population Council and the Navrongo Health Research Centre.

Fortes, Meyer. 1978. "Family, marriage, and fertility in West Africa," in C. Oppong, G. Adaba, M. Bekombo-Priso, and J. Mogey (eds.), Marriage, Fertility, and Parenthood in West Africa, pp. 17-54. Changing African Family Monograph Series No. 4, Volume 1. Canberra: Australian National University.

Gage, Anastasia J. and Caroline H. Bledsoe. 1994. "The effects of education and social stratification on marriage and the transition to parenthood in Freetown, Sierra Leone," in Bledsoe and Pison (eds.), pp. 148-164.

Ghana Statistical Service and Macro International. 1994. Ghana Demographic and Health Survey, 1993. Calverton, MD: Macro International.

Grindal, Bruce T. 1982. Growing Up in Two Worlds: Education and Transition among the Sisala of Northern Ghana. New York: Irvington Publishers.

Isiugo-Abanihe, Uche C. 1994. "Consequences of bridewealth changes on nuptiality patterns among the Ibo of Nigeria," in Bledsoe and Pison (eds.), pp. 74-91.

Kiragu, Karungari and Laurie S. Zabin. 1993. "The correlates of premarital sexual activity among school-age adolescents in Kenya," International Family Planning Perspectives 19, no. 3: 92-97, 109.

Knudsen, Christiana Oware. 1994. The Falling Dawadawa Tree: Female 
Circumcision in Developing Ghana. Højbjerg, Denmark: Intervention Press.

Leonard, Lori. 1996. "Female circumcision in southern Chad: Origins, meaning, and current practice," Social Science and Medicine 43, no. 2: 255263.

Lesthaeghe, Ron, Georgia Kaufmann, Dominique Meekers, and Johan Surkyn. 1994. "Post-partum abstinence, polygyny, and age at marriage: A macro-level analysis of sub-Saharan societies," in Bledsoe and Pison (eds.), pp. 25-54.

Meekers, Dominque. 1992. "The process of marriage in African societies: A multiple indicator approach," Population and Development Review 18, no. 1: 61-78.

Mensch, Barbara S., Judith Bruce, and Margaret E. Greene. 1998. The Uncharted Passage: Girls' Adolescence in the Developing World. New York: Population Council, forthcoming.

Naden, Tony (ed.). 1974. Kinship Terminology and Some of Its Social Correlates or Outworkings of the Kinship System in Ghanaian Culture. Legon, Ghana: Institute of African Studies, University of Ghana.

Nazzar, Alex et al. 1995. "Developing a culturally appropriate family planning program for the Navrongo experiment," Studies in Family Planning 25, no. 6: 307-324.

Ocholla-Ayayo, A. B. C. 1997. "HIV/AIDS risk factors and changing sexual practices in Kenya," in Thomas S. Weisner, Candice Bradley, and Philip L. Kilbride (eds.), African Families and the Crisis of Social Change, pp. 109-124. Westport, CT: Bergin \& Garvey.

Orubuloye, I. O., John C. Caldwell, and Pat Caldwell. 1991. "Sexual networking in the Ekiti District of Nigeria," Studies in Family Planning 22, no. 2: 61-73. 
Pitshandenge, Iman Ngondo A. 1994. "Marriage law in sub-Saharan Africa," in Bledsoe and Pison (eds), pp. 117-129.

Rahman, Anika, Laura Katzive, and Stanley K. Henshaw. 1998. “A global review of laws on induced abortion, 1985-1997," Family Planning Perspectives 24, no. 2: 56-64.

Rattray, R. S. 1932 (1969 edition). The Tribes of the Ashanti Hinterland, Vol. 1. Oxford: Oxford University Press.

Smock, Audrey Chapman. 1977. "The impact of modernization on women's position in the family in Ghana," in Alice Schlegel (ed.), Sexual Stratification: A Cross-Cultural View, pp. 192-214. New York: Columbia University Press.

Tonah, Steve. 1993. The Development of Agropastoral Households in Northern Ghana: Policy Analysis, Project Appraisal and Future Perspectives. Saarbrücken, Germany: Verlag Breitenbach Publishers.

van de Walle, Étienne and Dominique Meekers. 1994. "Marriage drinks and kola nuts," in Bledsoe and Pison (eds.), pp. 57-73.

Whiting, John W. M., Victoria Burbank, and Mitchell S. Ratner. 1986. "The duration of maidenhood across cultures," in Jane B. Lancaster and Beatrix A. Hamburg (eds.), School-Age Pregnancy and Parenthood: Biosocial Dimensions. New York: Aldine De Gruyter. pp. 273-302.

Wilson, Alexandra. 1998. Personal communication.

Worthman, Carol M. and John W. M. Whiting. 1987. "Social change in adolescent sexual behavior, mate selection, and premarital pregnancy rates in a Kikuyu community," Ethos 15, no. 2: 145-165. 


\title{
POLICY RESEARCH DIVISION WORKING PAPERS
}

\author{
Recent Back Issues
}

1996

*83 Sajeda Amin, Ian Diamond, and Fiona Steele, "Contraception and religious practice in Bangladesh."

84 John B. Casterline, Aurora E. Perez, and Ann E. Biddlecom, "Factors underlying unmet need for family planning in the Philippines."

85 Geoffrey McNicoll, "Governance of fertility transition: Regularity and duress."

*86 John Bongaarts, "Population pressure and the food supply system in the developing world."

87 Sajeda Amin, "Family structure and change in rural Bangladesh."

*88 John Bongaarts and Susan Cotts Watkins, "Social interactions and contemporary fertility transitions."
*89 Cynthia B. Lloyd and Mark R. Montgomery, "The consequences of unintended fertility for investments in children: Conceptual and methodological issues."

* 90 Zeba Sathar and Sonalde Desai, "Work patterns in rural Pakistan: Intersections between gender, family, and class."

*91 Mark R. Montgomery, "Learning and lags in mortality perceptions."

92 Ann E. Biddlecom, John B. Casterline, and Aurora E. Perez, "Men's and women's views of contraception."
93 James F. Phillips, Fred N. Binka, Martin Adjuik, Alex Nazzar, and Kubaze Frank Adazu, "The determinants of contraceptive innovation: A case-control study of family planning acceptance in a traditional African society."
94 John Bongaarts and Sajeda Amin, "Prospects for fertility decline and implications for population growth in South Asia."

95 Barbara S. Mensch and Cynthia B. Lloyd, "Gender differences in the

* No longer available 
schooling experiences of adolescents in low-income countries: The case of Kenya."

96 Martin Brockerhoff and Ellen Brennan, "The poverty of cities in the developing world."

97 Carol E. Kaufman, "Reproductive control in South Africa."

98 John Bongaarts, "Trends in unwanted childbearing in the developing world."

99 Mary Arends-Kuenning, "How do family planning workers' visits affect women's contraceptive behavior in Bangladesh?"

100 Mark R. Montgomery and Cynthia B. Lloyd, "Excess fertility, unintended births, and children's schooling."
101 Mary Arends-Kuenning, "The equity and efficiency of doorstep delivery of contraceptives in Bangladesh."

102 Sajeda Amin, Ian Diamond, Ruchira T. Naved, and Margaret Newby, "Transition to adulthood of female factory workers: Some evidence from Bangladesh."

*103 Margaret E. Greene and Ann E. Biddlecom, "Absent and problematic men: Demographic accounts of male reproductive roles."

104 Michael P. Todaro, "Urbanization, unemployment, and migration in Africa: Theory and policy."

105 Geoffrey McNicoll, "Population and poverty: A review and restatement."
106 Sajeda Amin and Gilda Sedgh, "Incentive schemes for school attendance in rural Bangladesh."

107 Martin Brockerhoff and Paul Hewett, "Ethnicity and child mortality in subSaharan Africa."

108 Ann E. Biddlecom and Bolaji M. Fapohunda, "Covert contraceptive use: Prevalence, motivations, and consequences."
109 John Bongaarts and Griffith Feeney, "On the quantum and tempo of fertility."

110 Barbara S. Mensch, Daniel Bagah, Wesley H. Clark, and Fred Binka, "The changing social environment for adolescents in the Kassena-Nankana District of northern Ghana: Implications for reproductive behavior." 